\title{
SARCOCYSTIS NEURONA INFECTIONS IN SEA OTTER (ENHYDRA LUTRIS): EVIDENCE FOR NATURAL INFECTIONS WITH SARCOCYSTS AND TRANSMISSION OF INFECTION TO OPOSSUMS (DIDELPHIS VIRGINIANA)
}

\author{
Author(s): J. P. Dubey, A. C. Rosypal , B. M. Rosenthal , N. J. Thomas , D. S. Lindsay , J. F. Stanek , S.
} M. Reed, and W. J A. Saville

Source: Journal of Parasitology, 87(6):1387-1393. 2001.

Published By: American Society of Parasitologists

DOI: http://dx.doi.org/10.1645/0022-3395(2001)087[1387:SNIISO]2.0.CO;2

URL: http://www.bioone.org/doi/full/10.1645/0022-3395\%282001\%29087\%5B1387\%3ASNIISO

$\% 5 \mathrm{D} 2.0 . \mathrm{CO} \% 3 \mathrm{~B} 2$

BioOne (www.bioone.org) is a nonprofit, online aggregation of core research in the biological, ecological, and environmental sciences. BioOne provides a sustainable online platform for over 170 journals and books published by nonprofit societies, associations, museums, institutions, and presses.

Your use of this PDF, the BioOne Web site, and all posted and associated content indicates your acceptance of BioOne's Terms of Use, available at www.bioone.org/page/terms_of_use.

Usage of BioOne content is strictly limited to personal, educational, and non-commercial use. Commercial inquiries or rights and permissions requests should be directed to the individual publisher as copyright holder. 


\title{
SARCOCYSTIS NEURONA INFECTIONS IN SEA OTTER (ENHYDRA LUTRIS): EVIDENCE FOR NATURAL INFECTIONS WITH SARCOCYSTS AND TRANSMISSION OF INFECTION TO OPOSSUMS (DIDELPHIS VIRGINIANA)
}

\author{
J. P. Dubey, A. C. Rosypal ${ }^{\star}$, B. M. Rosenthal, N. J. Thomas $\dagger$, D. S. Lindsay ${ }^{\star}$, J. F. Stanek $\neq$, S. M. Reed $\S$, and \\ W. J. A. Saville $\neq$ \\ Parasite Biology, Epidemiology and Systematics Laboratory, Animal and Natural Resources Institute, Agricultural Research Service, U.S. \\ Department of Agriculture, Building 1001, Beltsville, Maryland 20705-2350. e-mail: jdubey@anri.barc.usda.gov
}

\begin{abstract}
Although Sarcocystis neurona has been identified in an array of terrestrial vertebrates, recent recognition of its capacity to infect marine mammals was unexpected. Here, sarcocysts from 2 naturally infected sea otters (Enhydra lutris) were characterized biologically, ultrastructurally, and genetically. DNA was extracted from frozen muscle of the first of these sea otters and was characterized as S. neurona by polymerase chain reation (PCR) amplification followed by restriction fragment length polymorphism analysis and sequencing. Sarcocysts from sea otter no. 1 were up to $350 \mu \mathrm{m}$ long, and the villar protrusions on the sarcocyst wall were up to $1.3 \mu \mathrm{m}$ long and up to $0.25 \mu \mathrm{m}$ wide. The villar protrusions were tapered towards the villar tip. Ultrastructurally, sarcocysts were similar to $S$. neurona sarcocysts from the muscles of cats experimentally infected with $S$. neurona sporocysts. Skeletal muscles from a second sea otter failed to support PCR amplification of markers considered diagnostic for $S$. neurona but did induce the shedding of sporocysts when fed to a laboratory-raised opossum (Didelphis virginiana). Such sporocysts were subsequently fed to knockout mice for the interferon-gamma gene, resulting in infections with an agent identified as $S$. neurona on the basis of immunohistochemistry, serum antibodies, and diagnostic sequence detection. Thus, sea otters exposed to $S$. neurona may support the development of mature sarcocysts that are infectious to competent definitive hosts.
\end{abstract}

Although our understanding of the epizootiology of Sarcocystis neurona in terrestrial vertebrates has recently expanded, the appearance of this parasite in a marine mammal was unexpected. First recognized as the most important cause of equine protozoal myeloencephalitis (EPM) in horses in the United States (Dubey, Lindsay, Saville et al., 2001), an EPMlike disease has also been reported in raccoons (Procyon lotor), mink (Mustela vison), cats (Felis domesticus), striped skunks (Mephitis mephitis), zebras, sea otters (Enhydra lutris), and Pacific harbor seals (Phoca vitulina richardsi) (Dubey, Lindsay, Saville et al., 2001; Lindsay et al., 2001; Miller, Crosbie et al., 2001; Miller, Sverlow et al., 2001). Sarcocystis neurona has an unusual life cycle (Dubey et al., 2000). Opossums (Didelphis virginiana and $D$. albiventris) are definitive hosts and excrete sporocysts in their feces. Horses and other aberrant hosts become infected by ingesting food, water, or both contaminated with sporocysts. Recently, cats, skunks, nine-banded armadillos (Dasypus novemcinctus), and raccoons were found to be intermediate hosts for S. neurona (Dubey et al., 2000; Cheadle, Tanhauser et al., 2001; Cheadle, Yowell et al., 2001; Dubey, Saville et al., 2001; Tanhauser et al., 2001); sarcocysts from these hosts induced sporocysts in opossums. In the present study, the sea otter was identified as a natural intermediate host for $S$. neurona.

\section{MATERIALS AND METHODS}

\section{Naturally infected sea otters}

Sarcocysts from 2 naturally infected sea otters were studied. Sea otter no.1 was reported by Lindsay et al. (2000); S. neurona was isolated in

Received 11 June 2001; revised 2 October 2001; accepted 2 October 2001

* Center for Molecular Medicine and Infectious Diseases, Department of Biomedical Sciences and Pathobiology, Virginia-Maryland Regional College of Veterinary Medicine, Virginia Tech, 1410 Prices Fork Road, Blacksburg, Virginia 24061-0342.

$\dagger$ Department of the Interior, U.S. Geological Survey, National Wildlife Health Center, 6006 Schroeder Road, Madison, Wisconsin 53711.

$\$$ Department of Veterinary Preventive Medicine, College of Veterinary Medicine, Ohio State University, Columbus, Ohio 43210-1092.

$\S$ Department of Large Animal Medicine, College of Veterinary Medicine, Ohio State University, Columbus, Ohio 43210-1092. culture from the brain of this animal. Numerous sarcocysts were seen in histologic sections of skeletal muscles fixed in buffered neutral $10 \%$ formalin. For the present study, formalin-fixed muscles were postfixed in osmium and processed for transmission electron microscopy (Dubey et al., 2000). Retrospectively, muscle tissue frozen at $-20 \mathrm{C}$ for $18 \mathrm{mo}$ was processed for DNA characterization by polymerase chain reaction (PCR) and sequencing.

Sea otter no. 2 was an adult female northern sea otter reported alive but in distress on a beach at Olympic National Park, Washington. It reportedly had trouble supporting weight on its hind legs, but it swam out to sea. It was again seen alive the next morning but was found dead that afternoon on the beach. The carcass was refrigerated for 5 days and then shipped chilled by overnight commercial carrier for necropsy. After sarcocysts were seen in histologic sections of the muscles, muscles were shipped cold for feeding to a laboratory-raised opossum (no. 25), 9 days after death of the otter.

Samples of otter brain, spinal cord, trigeminal ganglion, lung, heart, liver, kidney, urinary bladder, spleen, thymus, lymph nodes, uterus, ovary, skeletal muscle, thyroid gland, adrenal gland, pituitary gland, and intestine were fixed for histopathology. Paraffin-embedded sections were stained with hematoxylin and eosin and examined microscopically.

\section{Polymerase chain reaction}

Frozen skeletal muscle from sea otter no. 1 and muscle from sea otter no. 2 were stored at $4 \mathrm{C}$ for $2 \mathrm{wk}$ and then examined for $S$. neurona DNA by PCR (Tanhauser et al., 1999). The DNA was extracted from $0.5 \mathrm{~g}$ of skeletal muscle using a commercial DNA extraction kit (DNA Maxi Kit, Quiagen, Valencia, California). The purified DNA was diluted 1:100, and a $20-\mu l$ aliquot was taken and mixed with $200 \mu \mathrm{m}$ of InstaGene Matrix (Bio Rad, Hercules, California). The samples were then incubated in a $56 \mathrm{C}$ water bath for $30 \mathrm{~min}$. The samples were vortexed, placed in boiling water for $8 \mathrm{~min}$, vortexed again, and centrifuged in a microfuge for 2-3 min. A $20-\mu l$ aliquot of the supernatant was used per $50-\mu 1$ PCR. The remaining supernatant was stored at -20 C. The PCR was performed on each sample using Ready To Go PCR Beads (Amersham Pharmacia Biotech, Piscataway, New Jersey) and a Hybaid OmniGene thermocycler. Standard PCR conditions were used with the following amplification parameters: $94 \mathrm{C}$ for $5 \mathrm{~min}$; 40 cycles of $94 \mathrm{C}$ for $60 \mathrm{sec}, 50 \mathrm{C}$ for $75 \mathrm{sec}$, and $72 \mathrm{C}$ for $60 \mathrm{sec}$; and $72 \mathrm{C}$ for $10 \mathrm{~min}$. The PCR products were electrophoresed on a $1 \%$ agarose gel. An $\sim 1,100$-base pair (bp) PCR product was amplified using primers JNB33 (5'-CGAACAGAGATGAGGAAAAT-3') and JNB54 (5'GTTGTGGTGTTGCGTGAGTC-3') described by Tanhauser et al. (1999). The PCR products were digested separately with restriction enzymes Hin fI or Dra I (Promega, Madison, Wisconsin) and were analyzed by electrophoresis on a $1 \%$ agarose gel with appropriate size 

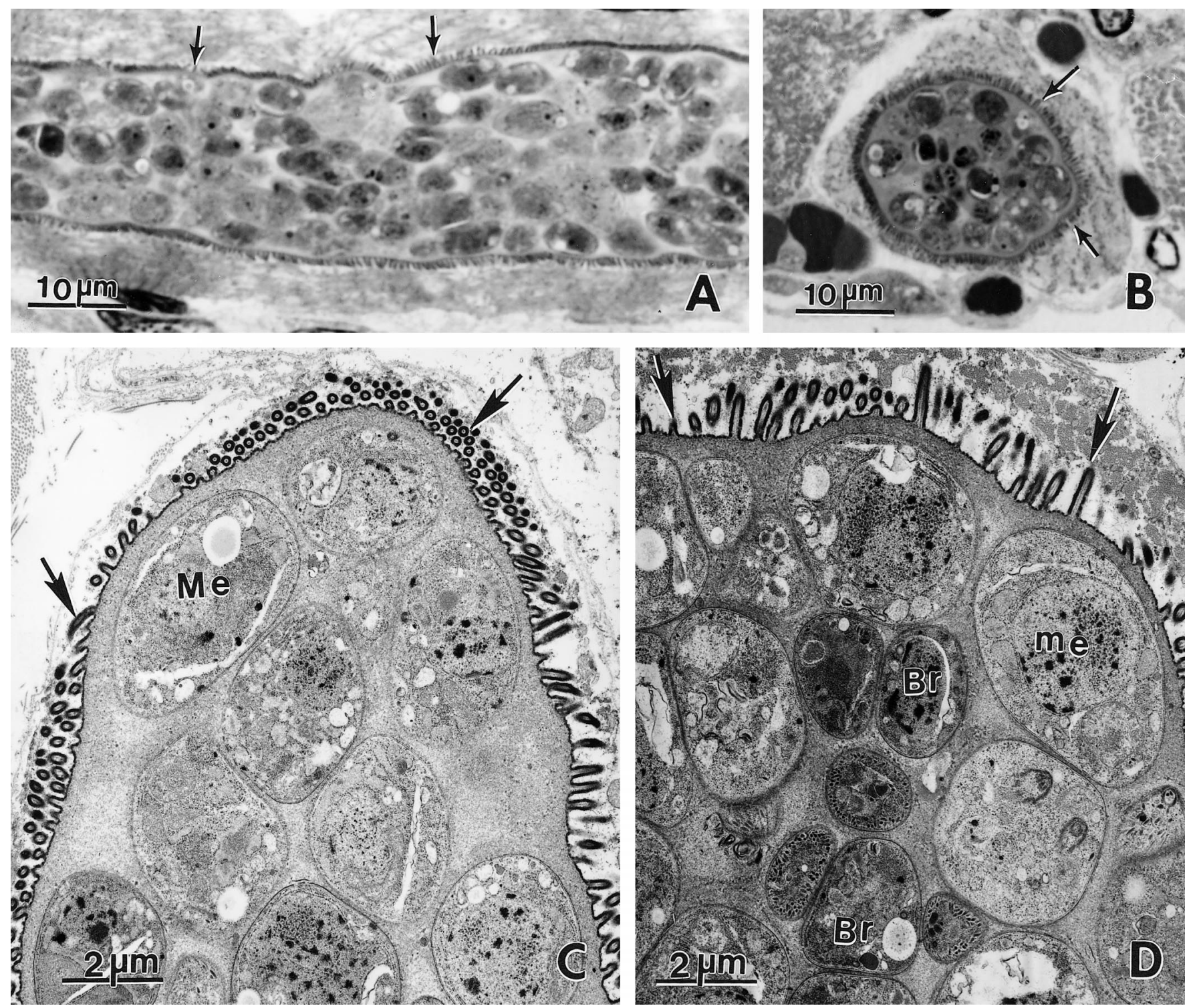

FigURE 1. Sarcocysts of Sarcocystis neurona in naturally infected sea otter no. 1. A, B. Note minute villar protrusions (arrows) and variable thickness of the cyst wall depending on folding of villi. One-micrometer-thick sections, toluidine blue. C, D. Transmission electron micrographs of 2 sarcocysts. Note different length and shape of villar protrusions (arrows) on the sarcocyst wall, depending on plane of section and folding of villi. Most organisms are metrocytes $(\mathrm{Me})$; only a few bradyzoites $(\mathrm{Br})$ are present.

markers. Merozoite DNA from the SN6 strain of S. neurona (Dubey et al., 1999) was used as a positive control.

In a separate laboratory, 500-mg slices of tissue were digested with proteinase $\mathrm{K}$ and DNA extracted using DNAeasy columns (Quiagen) as per the manufacturer's recommendations. Amplification and direct bidirectional sequencing of the internal transcribed spacer region (ITS) and second diagnostic locus (25/396; Tanhauser et al., 1999) were conducted as previously described (Rosenthal et al., 2001).

\section{Feeding of sea otter muscles to an opossum}

A laboratory-raised 6-mo-old opossum was housed at the Ohio State University (OSU) in a cage with wood chips for bedding and fed dry dog food and water ad libitum. Its cage was cleaned daily. Feces were collected for sporocyst evaluation prior to feeding infected muscles to the opossum and were collected daily until necropsy. Details of source of the opossum, housing, and fecal flotations were previously reported (Dubey et al., 2000). The opossum (no. 25) was fed meat from sea otter no. 2 for 11 days and euthanized on the 12th day.
Sporocysts were not detected in opossum feces prior to feeding of sea otter muscle, which was initiated on day 0 . After the opossum was euthanized, the small intestine was removed and tied at the ileum and pylorus ends. The small intestine was shipped on ice to the USDA laboratory in Beltsville, Maryland. The intestine was subsequently processed for sporocyst collection. Sporocyst were counted using a hemocytometer and stored in antibiotics at $4 \mathrm{C}$ as described by Dubey (2000, 2001).

\section{Bioassay of sea otter sporocysts in knockout mice}

Sporocysts derived from the opossum (no. 25) that had been fed muscle tissue from sea otter no. 2 were fed to each of the 5 interferongamma gene knockout (KO) mice as described by Dubey and Lindsay (1998) and Dubey (2001). The KO mice were euthanized 7, 14, 21, 24 and 26 days later to study the localization of $S$. neurona in different tissues (Table 1). 

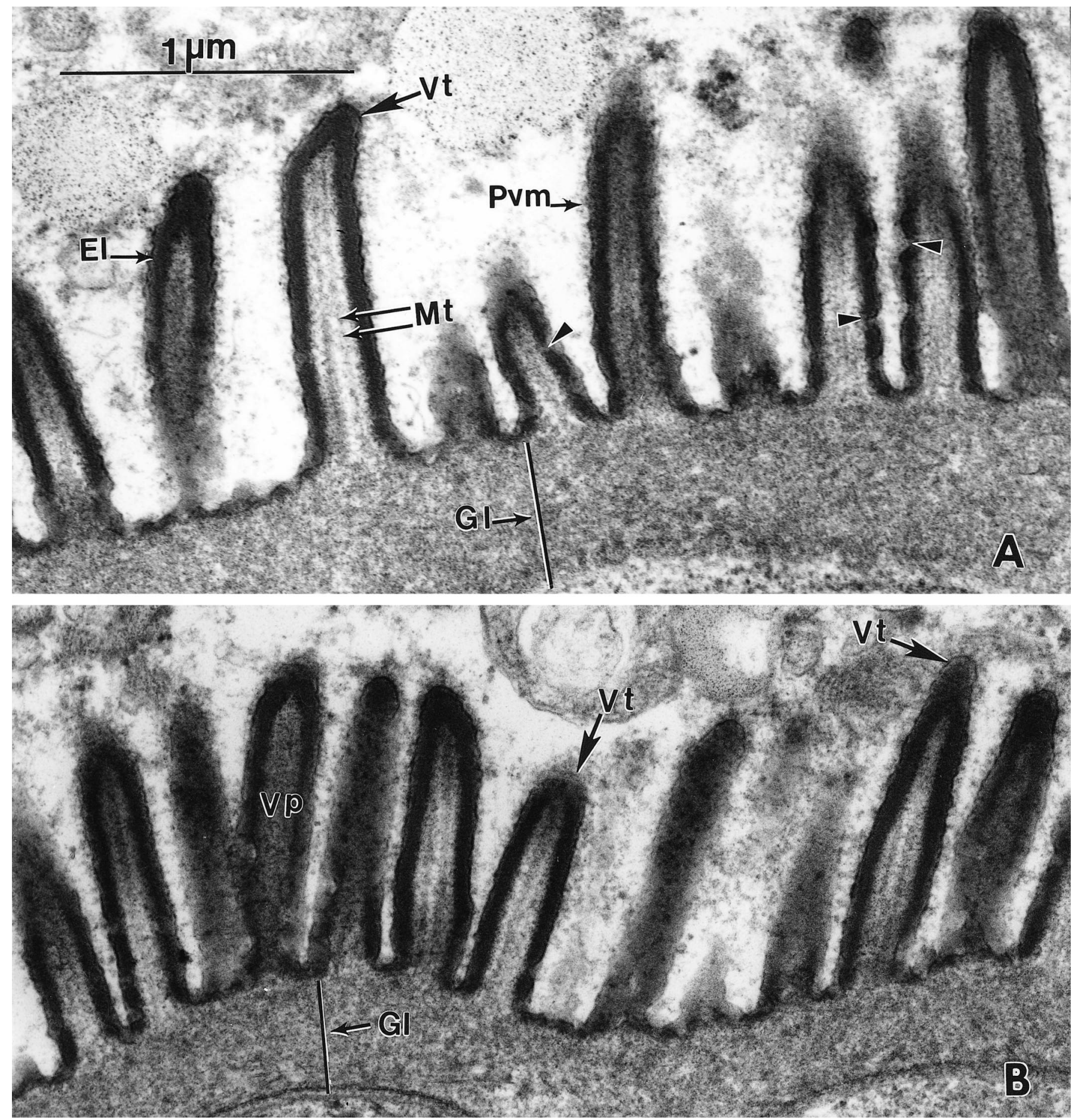

FIGURE 2. Transmission electron micrographs of 2 sarcocysts of Sarcocystis neurona in sea otter no. 1. Note villar protrusions (Vp) with villar tip ( $\mathrm{Vt}$ ) bent at different angles, differences in heights of $\mathrm{Vp}$, a thick electron-dense layer (El) lining the parasitophorous vacuolar membrane (Pvm), and smooth granular layer (Gl). Microtubules in Vp do not extend into the Gl.

\section{Histological and immunohistochemical examinations}

The KO mice that were euthanized or died were neocropsied. Representative sections of all major organs were fixed in buffered neutral $10 \%$ formalin and processed for histology. Paraffin-embedded sections were cut at $5 \mu \mathrm{m}$ and examined after staining with hematoxylin and eosin. For immunohistochemical staining, paraffin-embedded sections were treated with anti-S. neurona antibodies as previously described (Dubey and Hamir, 2000).

\section{Serological examination for $\boldsymbol{S}$. neurona antibodies}

Serum samples from mice were examined for anti-S. neurona antibodies using the $S$. neurona direct agglutination test as described by Lindsay and Dubey (2001).

\section{In vitro cultivation of $S$. neurona}

Attempts were made to culture protozoa from the tissues of $\mathrm{KO}$ mice fed sporocysts (Table 1). Mouse tissues were homogenized in Hank's 


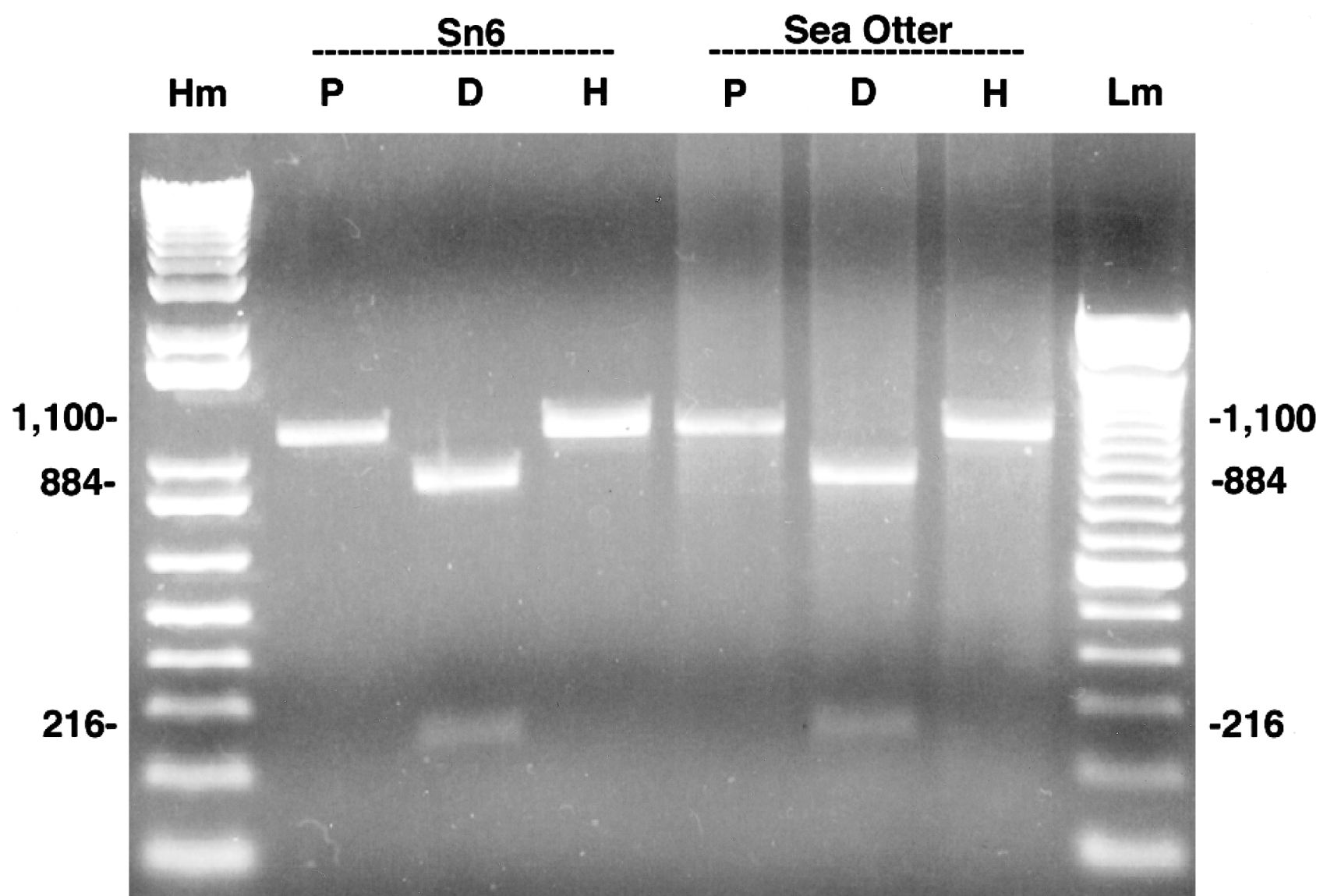

FIgURE 3. Results of PCR (P) followed by Dra I (D) and Hin fI (H) restriction enzyme digestion of DNA from Sarcocystis neurona (Sn6) and from the southern sea otter (no. 1). $\mathrm{Hm}=$ high-molecular-mass marker; $1 \mathrm{~m}=$ low-molecular-mass marker.

balanced salt solutions and inoculated onto bovine monocytes as previously described (Dubey et al., 1999). After $2 \mathrm{hr}$ of incubation in a tissue culture flask at $37 \mathrm{C}$, the culture medium was decanted. Fresh culture medium was added to the flask and the original culture was monitored for up to 60 days. If no growth of protozoa was obtained, the culture flask was discarded.

\section{RESULTS}

Sarcocysts in sea otter no. 1 were microscopic, up to 350 $\mu \mathrm{m}$ long and up to $40 \mu \mathrm{m}$ wide. The sarcocyst wall was $\sim 1$

TABLE I. Sarcocystis neurona infection in KO mice fed sporocysts from opossum that was fed muscle from naturally infected sea otter.

\begin{tabular}{|c|c|c|c|c|}
\hline \multirow[b]{2}{*}{$\begin{array}{c}\text { Mouse } \\
\text { no. }\end{array}$} & \multirow{2}{*}{$\begin{array}{c}\text { Day } \\
\text { euthanized/ } \\
\text { died* }\end{array}$} & \multicolumn{2}{|c|}{ Tissues positive for $S$. neurona $\dagger$} & \multirow{2}{*}{$\begin{array}{c}\text { S. neurona } \\
\text { agglutination } \\
\text { test }\end{array}$} \\
\hline & & $\begin{array}{l}\text { Immunohisto- } \\
\text { chemistry }\end{array}$ & Cell culture & \\
\hline 4605 & E7 & $\mathrm{L}$ & $\mathrm{S}, \mathrm{H}, \mathrm{L}$ & ND \\
\hline 4607 & E14 & $\mathrm{H}, \mathrm{L}$ & $\mathrm{S}, \mathrm{H}, \mathrm{L}$ & $\geq 1,000$ \\
\hline 4623 & E14 & $\mathrm{B}, \mathrm{H}, \mathrm{K}, \mathrm{L}$ & ND & ND \\
\hline 4619 & E21 & $\mathrm{B}, \mathrm{H}, \mathrm{L}, \mathrm{T}$ & B & $\geq 1,000$ \\
\hline 4620 & DE24 & B & B & 100 \\
\hline 4621 & D26 & B & ND & $\geq 1,000$ \\
\hline 4622 & DE26 & $\mathrm{B}, \mathrm{H}$ & ND & 100 \\
\hline
\end{tabular}

* $\mathrm{E}=$ euthanized; $\mathrm{D}=$ died; $\mathrm{DE}=$ euthanized when ill.

$\dagger \mathrm{B}=$ brain; $\mathrm{H}=$ heart; $\mathrm{K}=$ kidney; $\mathrm{L}=$ lung; $\mathrm{S}=$ spleen; $\mathrm{ND}=$ not done. $\mu \mathrm{m}$ thick. The structure of the sarcocyst wall was not clear in 5 - $\mu \mathrm{m}$-thick sections stained with hematoxylin and eosin. In 1$\mu \mathrm{m}$-thick sections stained with toluidine blue, small villar protrusions (Vp) were visible (Fig. 1A, B). The sarcocysts were immature and appeared to be at the same stage of development.

Nine sarcocysts were examined ultrastructurally. Slender Vp were visible throughout the sarcocyst, and the thickness of the sarcocyst wall varied with the plane of section (Fig. 1C, D). The parasitophorous vacuolar membrane was lined by a 50 75-nm-thick electron-dense layer that was interrupted at irregular distances (Fig. 2). The Vp were slender, with a maximum length of $1.3 \mu \mathrm{m}$ and a maximum width of $0.25 \mu \mathrm{m}$, and were tapered toward the tip. The tapered end of the Vp was $0.1-0.7$ $\mu \mathrm{m}$ long. Some Vp appeared constricted at the base, whereas others were wider than the width of the $\mathrm{Vp}$ at midlength. One to 3 microtubules were present from tip to the base of the $\mathrm{Vp}$ in any given section. The granular layer was $\sim 0.4 \mu \mathrm{m}$ thick at points where metrocytes and bradyzoites were present. Most organisms in sarcocysts were metrocytes, and only a few bradyzoites were present.

From DNA extracted from the tissues of sea otter no. 1, an approximately 1,100-bp PCR product was amplified. A product of similar size was obtained from the SN6 strain of $S$. neurona, which served as a positive control. Each of these fragments were cut into 884 - and 216-bp segments by Dra I but were not 

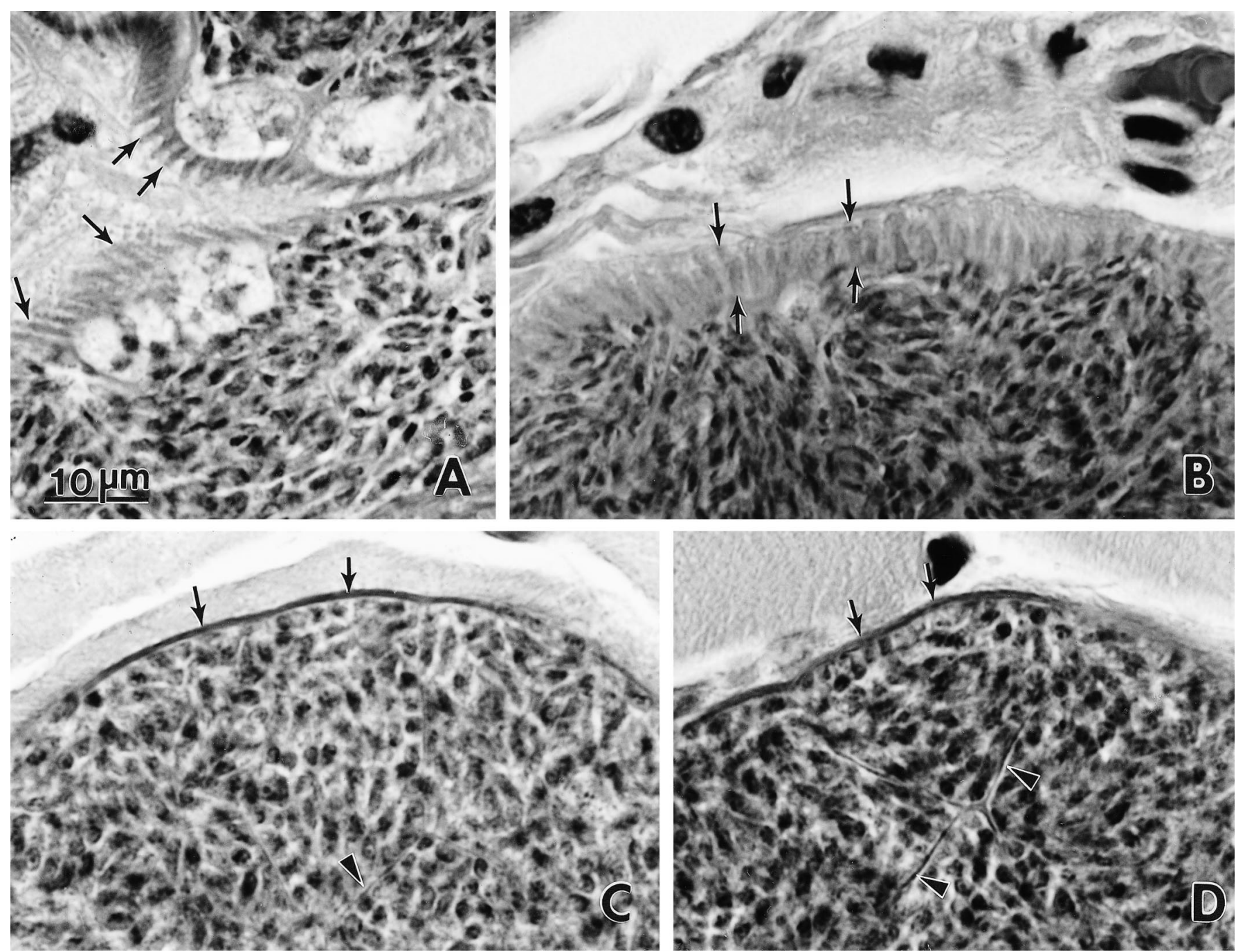

FIGURE 4. Sarcocysts in tissues from sea otter no. 2 naturally infected with Sarcocystis. Hematoxylin and eosin. Bar applies to all parts. A, B. Tongue. Note villar protrusions (arrows) on sarcocyst walls. C, D. Skeletal muscle. Note thin-walled $(<1 \mu \mathrm{m})$ sarcocysts without visible villar protrusions (arrows). Also note septa (arrowheads).

digested by Hin fI (Fig. 3). Muscle tissues from sea otter no. 1 also supported the amplification of another locus (25/396) when subjected to independent extraction and amplification procedures in a second laboratory. Its sequence was identical to that previously reported for the merozoites previously recovered from the brain of this southern sea otter (Lindsay et al., 2000; Rosenthal et al., 2001). The ITS-1 locus was identical to that previously reported for $S$. neurona isolates from a horse in Missouri (Marsh et al., 1999).

In sea otter no. 2, protozoa and lesions were confined to muscles, brain, and spinal cord. Minimal perivascular cuffing of mononuclear cells was seen in the brain and spinal cord; protozoa were not seen. Sarcocystis neurona DNA was not detected in muscle extracts of sea otter no. 2.

Mature sarcocysts were seen in skeletal muscles of sea otter no. 2. Two sarcocysts $(350 \times 200 \mu \mathrm{m}$ and $330 \times 190 \mu \mathrm{m})$ were seen in a section of tongue (Fig. 4A, B). In both of these sarcocysts, the sarcocyst wall had slender to conical Vp up to 7 $\mu \mathrm{m}$ long, depending on the plane of the section (Fig. 4A, B). Sarcocysts were not seen in subsequent sections of tongue.

Seven sarcocysts were seen in 3 sections of skeletal muscle (Fig. 4C, D). These sarcocysts were 50-210 $\times 40-190 \mu \mathrm{m}$. The sarcocyst wall was $<1 \mu \mathrm{m}$ thick, and $\mathrm{Vp}$ were not visible at the light microscope level (Fig. 4C, D).

The opossum fed muscle from sea otter no. 2 started shedding sporocysts in feces on day 11 , and a few $(<100,000)$ sporocysts were collected from its intestinal scrapings at necropsy on day 12.

Sarcocystis neurona was identified immunohistochemically in tissues of $\mathrm{KO}$ mice, and serum antibodies to $S$. neurona were found in KO mice fed sporocysts from the sea otter (Table 1). The localization of $S$. neurona in tissues of KO mice fed sporocysts from the sea otter was the same as those fed sporocysts from naturally infected opossums (Dubey, 2001). The 25/396 locus from the brain of a mouse (no. 4621) fed sporocysts from this opossum was identical to that previously reported for $S$. 
neurona strain UCD-01 (GenBank Accession AF093158) over its entire $285 \mathrm{bp}$.

\section{DISCUSSION}

The sea otter was identified as a natural intermediate host of S. neurona based on shedding of S. neurona sporocysts by a laboratory-raised opossum fed muscle from sea otter no. 2. The KO mice fed sporocysts developed neurologic signs, S. neurona was identified immunohistochemically in tissues of KO mice, $S$. neurona antibodies were detected in sera of $\mathrm{KO}$ mice, and S. neurona was isolated from tissues of KO mice fed sporocysts from the sea otter.

In addition, sarcocysts in sea otter no. 1 were structurally similar to $S$. neurona sarcocysts in experimentally infected cats (Dubey et al., 2000; Dubey, Lindsay, Fritz, and Speer, 2001). The use of a single inoculum may explain the apparent age uniformity of the observed immature sarcocysts. In cattle, the presence of many immature sarcocysts of about the same stage of development has been used to diagnose subacute muscular sarcocystosis (Dubey et al., 1989).

The DNA isolated from muscle of sea otter no. 1 was similar to $S$. neurona DNA (Tanhauser et al., 1999). For unknown reasons, neither locus 25/396 nor locus 33/54 were successfully amplified from the muscle of sea otter no. 2; however, the opossum fed muscle from this sea otter shed sporocysts that were subsequently confirmed by serological and genetic methods to induce $S$. neurona infections in mice. A 2 -wk interval between the death of sea otter no. 2 and feeding its muscle to opossum no. 25 may account for the scarcity of recovered sporocysts.

The $\mathrm{Vp}$ of sarcocysts in tongue and skeletal muscle of sea otter no. 2 were distinct from those typical of $S$. neurona sarcocysts; $\mathrm{Vp}$ in $S$. neurona are generally more slender than those seen in sea otter no. 2. Thus, more than 1 species of Sarcocystis probably infected this sea otter. Rosonke et al. (1999) found sarcocysts in skeletal muscles of a sea otter with $S$. neuronaassociated encephalitis, but the lack of detail in the illustration provided precludes direct comparison of these sarcocyst with those found in the sea otter.

The fixed genetic signature maintained by a parasite throughout its many life-cycle stages and across its various hosts strengthens our ability to identify and systematically classify parasites. Thus, genetic markers initially developed to differentiate sporocysts shed by the opossum are useful in diagnosing tissue-stage infections. However, there are 2 important limitations. First, in cases such as this where more than 1 parasite may be present in a host tissue, the precise source of template DNA cannot be known with certainty using gross tissue preparations. Second, the specificity of PCR assays to selectively amplify DNA from a particular species can only be established over time as more parasite isolates are tested. Marked sequence uniformity characterizes those $S$. neurona isolates characterized thus far.

To date, the only known hosts capable of completing the $S$. neurona life cycle and shedding it sporocysts are opossums of the genus Didelphis. How sea otters in their natural habitat become infected with $S$. neurona is unknown. Whether S. neurona sporocysts are transported from opossum feces to sea otters via paratenic hosts or whether there is a natural predator of sea otters that excretes $S$. neurona sporocysts remains to be re- solved. In this respect, the identification of S. neurona sarcocysts in sea otters may be epidemiologically important.

\section{ACKNOWLEDGMENT}

A.C.R. and D.S.L. were supported in part by AH\&D project 137180.

\section{LITERATURE CITED}

Cheadle, M. A., S. M. Tanhauser, J. B. Dame, D. C. Sellon, M. Hines, P. E. Ginn, R. J. MacKay, and E. C. Greiner. 2001. The nine-banded armadillo (Dasypus novemcinctus) is an intermediate host for Sarcocystis neurona. International Journal for Parasitology 31: $330-335$.

, C. A. Yowell, D. C. Selton, M. Hines, P. E. Ginn, A. E. Marsh, J. B. Dame, and E. C. Greiner. 2001. The striped skunk (Mephitis mephitis) is an intermediate host for Sarcocystis neurona. International Journal for Parasitology 31: 843-849.

Dubey, J. P. 2000. Prevalence of Sarcocystis species sporocysts in wild caught opossums (Didelphis virginiana). Journal of Parasitology 86: $705-710$.

2001. Migration and development of Sarcocystis neurona in tissues of interferon gamma knockout mice fed sporocysts from a naturally infected opossum. Veterinary Parasitology 95: 341-351.

, AND A. N. HAMIR. 2000. Immunohistochemical confirmation of Sarcocystis neurona infections in raccoons, mink, cat, skunk and pony. Journal of Parasitology 86: 1150-1152.

, AND D. S. LINDSAY. 1998. Isolation in immunodeficient mice of Sarcocystis neurona from opossum (Didelphis virginiana) faeces, and its differentiation from Sarcocystis falcatula. International Journal for Parasitology 28: 1823-1828.

- D. Fritz, And C. A. SpeEr. 2001. Structure of Sarcocystis neurona sarcocysts. Journal of Parasitology 87: 13231327.

, - W. J. A. Saville, S. M. Reed, D. E. Granstrom, and C. A. SpeER. 2001. A review of Sarcocystis neurona and equine protozoal myeloencephatitis (EPM). Veterinary Parasitology 95: 89-131.

, D. E. Mattson, C. A. Speer, R. J. Baker, D. M. Mulrooney, S. J. Tornquist, A. N. Hamir, and T. C. Gerros. 1999. Characterization of Sarcocystis neurona isolate (SN6) from a naturally infected horse from Oregon. Journal of Eukaryotic Microbiology 46: $500-506$.

W. J. A. Saville, D. S. Lindsay, R. W. Stich, J. F. Stanek, C. A. Speer, B. M. Rosenthal, C. J. Njoku, O. C. H. Kwok, S. K. Shen, AND S. M. ReED. 2000. Completion of the life cycle of Sarcocystis neurona. Journal of Parasitology 86: 1276-1280.

, C. A. Speer, And R. Fayer. 1989. Sarcocystosis of animals and man. CRC Press, Boca Raton, Florida, 215 p.

, J. F. Stanek, D. S. Lindsey, B. M. Rosenthal, M. J. Oglesbee, A. C. Rosypal, C. J. NJoku, R. W. Stich, O. C. H. Kwok, S. K. Shen, A. N. Hamir, and S. M. Reed. 2001. Sarcocystis neurona infections in raccoons (Procyon lotor): Evidence for natural infection with sarcocysts, transmission of infection to opossums (Didelphis virginiana), and experimental induction of neurologic disease in raccoons. Veterinary Parasitology 100: 117-129.

LindSAY, D. S., AND J. P. Dubey. 2001. Direct agglutination test for the detection of antibodies to Sarcocystis neurona in experimentally infected animals. Veterinary Parasitology 95: 179-186.

- N. J. Thomas, AND J. P. DuBEy. 2000. Biological characterization of Sarcocystis neurona from a southern sea otter (Enhydra lutris nereis). International Journal for Parasitology 30: 617-624.

- - A. C. Rosypal, And J. P. Dubey. 2001. Dual Sarcocystis neurona and Toxoplasma gondii infection in a northern sea otter from Washington state, USA. Veterinary Parasitology 97: 319-327.

Marsh, A. E., B. C. Barr, L. Tell, D. D. Bowman, P. A. Conrad, C. KeTCHERSIDE, AND T. GREEN. 1999. Comparison of the internal transcribed spacer, ITS-1, from Sarcocystis falcatula and Sarcocystis neurona. Journal of Parasitology 85: 750-757.

Miller, M. A., P. R. Crosbie, K. Sverlow, K. Hanni, B. C. Barr, N. Kock, M. J. Murray, L. J. Lowenstine, and P. A. Conrad. 2001. Isolation and characterization of Sarcocystis from brain tissue of a 
free-living southern sea otter (Enhydra lutris nereis) with fatal meningoencephalitis. Parasitology Research 87: 252-257.

, K. Sverlow, P. R. Crosbie, B. C. Barr, L. J. Lowenstine, F. M. Gulland, A. PACKham, AND P. ConRad. 2001. Isolation and charaterization of two parasitic protozoa from a Pacific harbor seal (Phoca vitulina richardsi) with meningoencephalomyelitis. Journal of Parasitology 87: 816-822.

Rosenthal, B. M., D. S. Lindsay, AND J. P. Dubey. 2001. Relationships among Sarcocystis species transmitted by New World opossums (Didelphis spp.). Veterinary Parasitology 95: 133-142.

Rosonke, B. J., S. R. Brown, S. J. Tornquist, S. P. SNyder, M. M.
GARNER, AND L. L. BLythe. 1999. Encephalomyelitis associated with a Sarcocystis neurona-like organism in a sea otter. Journal of American Veterinary Medical Association 215: 1839-1842.

Tanhauser, S. M., M. A. Cheadle, E. T. Massey, B. A. Mayer, D. E. Schroeder, J. B. Dame, E. C. Greiner, and R. J. MacKay. 2001. The nine-banded armadillo (Dasypus novemcinctus) is naturally infected with Sarcocystis neurona. International Journal for Parasitology 31: 325-329.

C. A. Yowell, T. J. Cutler, E. C. Greiner, R. J. MacKay, AND J. B. DAME. 1999. Multiple DNA markers differentiate Sarcocystis neurona and Sarcocystis falcatula. Journal of Parasitology 85: $221-228$. 